\title{
SUB1 wt Allele
}

National Cancer Institute

\section{Source}

National Cancer Institute. SUB1 wt Allele. NCI Thesaurus. Code C52148.

Human SUB1 wild-type allele is located in the vicinity of 5p13.3 and is approximately $18 \mathrm{~kb}$

in length. This allele, which encodes activated RNA polymerase II transcriptional coactivator p15 protein, plays a role in chromatin organization. 